\title{
CREDIT SUPPORT FOR EXPORT: EVIDENCE FROM THE CZECH REPUBLIC
}

\author{
Karel Janda \\ Eva Michalíková \\ Jiří Skuhrovec
}
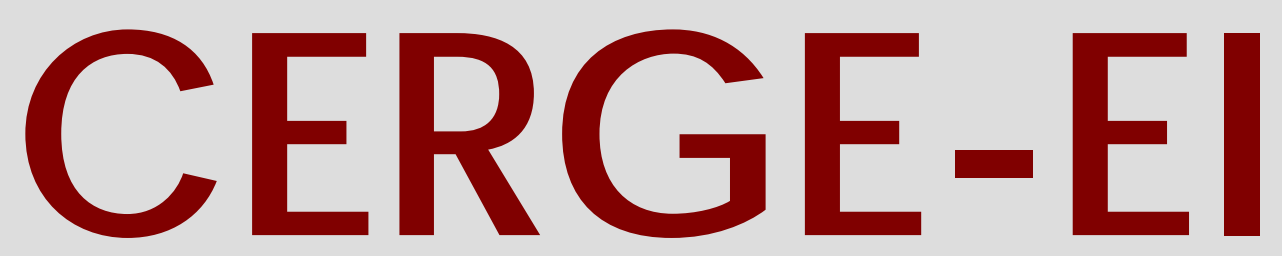

Charles University Centerfor Economic Research and Graduate Education Academy of Sciences of the Czech Republic Ec onomic s Institute 


\title{
Working Paper Series \\ 461 (ISSN 1211-3298)
}

\section{Credit Support for Export: Evidence from the Czech Republic}

\author{
Karel Janda \\ Eva Michalíková \\ Jiří Skuhrovec
}

CERGE-EI

Prague, May 2012 
ISBN 978-80-7343-264-5 (Univerzita Karlova. Centrum pro ekonomický výzkum a doktorské studium)

ISBN 978-80-7344-256-9 (Národohospodářský ústav AV ČR, v.v.i.) 


\title{
Credit Support for Export:Evidence from the Czech Republic*
}

\author{
Karel Janda ${ }^{\dagger}$ Eva Michalikova ${ }^{\ddagger}$ Jiri Skuhrovec $\S$
}

\author{
May 2012
}

\begin{abstract}
This paper deals with export credit promotion in the Czech Republic. The development and structure of Czech trade and export support is presented first. This is followed by an econometric analysis of the gravity model of Czech trade. A panel of 160 countries in 1996-2008 is analyzed and two gravity models of exports for the Czech Republic are estimated, the static model by fixed effects (LSDV estimator) and the dynamic model by System GMM. Finally, robust LTS estimator is used. We show that guarantees are a significant factor that influences positively the volume of exports in the Czech Republic.

\section{Abstrakt}

Tento článek se zabývá podporou exportu v České republic. Nejprve prezentuje vývoj a strukturu českého zahraničního obchodu a jeho podpory. Poté následuje ekonometrická analýza gravitačního modelu českého zahraničního obchodu. Je analyzován panel 160 zemí v letech 1996-2008 a jsou odhadnuty dva gravitační modely českých vývozů, statický model fixních efektů (LSDV) a dynamický model (GMM). Nakonec je použita robustní LTS metoda. Ukazujeme, že garance jsou důležitým faktorem, který kladně ovlivňuje objem českých vývozů.
\end{abstract}

Keywords: export, government promotion, gravity model, panel data

JEL classification: F14, G28, C23

${ }^{*}$ We thank Vladimir Benacek, Peter Egger, Marian Grendar, Jan Hanousek and anonymous reviewers and participants at a number of seminar and conference presentations for helpful comments on earlier drafts of this paper. Vera Potacelova and Lucia Psenakova provided excellent research assistance. Karel Janda acknowledges research support provided during his long-term visits at University of California, Berkeley and Australian National University (EUOSSIC programme). Our research was supported by the grants P403/10/1235, P402/11/0948, and P402/12/0982 of the Czech Science Foundation, institutional support VSE IP100040 and research project of VUT in Brno no. FP-S-12-1. The views expressed here are those of the authors and not necessarily those of our institutions. All remaining errors are solely our responsibility.

${ }^{\dagger}$ Institute of Economic Studies of the Faculty of Social Sciences of Charles University, University of Economics, Prague, and Affiliate Fellow at CERGE-EI. Correspondence address: IES FSV UK, Opletalova 26, 11000 Praha 1, Czech Republic, Karel-Janda@seznam.cz.

${ }^{\ddagger}$ Institute of Economic Studies of the Faculty of Social Sciences of Charles University and Faculty of Business and Management of Brno University of Technology. michalikova@volny.cz.

§Institute of Economic Studies of the Faculty of Social Sciences of Charles University. jskuhrovec@gmail.com. 


\section{Introduction}

An important feature common for all former socialist economies was the drastic change in their international trade patterns. At the start of economic transition in the early 90s, all these economies sharply reoriented their trade away from their former Comecon partners (The Council for Mutual Economic Assistance, 1949-1991, was an economic organization comprising the countries of the Eastern Bloc along with a number of communist states elsewhere in the world). They also politically rejected former state-directed and subsidized trade in favor of a free-trade approach. However, in the mid-nineties the early free-trade sentiment was gone and the battle for the return to lost markets began. This was the time that new government policies to support exports appeared.

This paper deals with this new export support in advanced transition economies using the example of the Czech Republic. Our analysis covers the period from 1996 to 2008. We show that the export credit support provided by the state-owned Czech Export Bank (CEB) exercised a significant positive influence on the growth of Czech exports while controlling for political risk, trade costs and size of the trading economies.

Our results are based on the gravity model of international trade which has been introduced by Tinbergen (1962) and Pöyhönen (1963). According to the gravity model, trade flows between two countries depend on the economic size of the countries and on "trade resistance" (especially geographical distance) between them. Anderson (1979), Bergstrand (1985), Anderson and van Wincoop (2003) and many others provide theoretical foundations of the gravity relationship in a general equilibrium framework instead of the initial motivation based on the physical law of gravitation.

Since "the gravity equation has dominated empirical research in international trade" (Helpman, Melitz and Rubinstein, 2008, p.442), it is natural that it was used by Egger and Url (2006), Moser, Nestmann, and Wedow (2008) and Baltensperger and Herger (2009) in their empirical papers dealing with public export promotion. 
Baltensperger and Herger (2009) analyze public export insurance in OECD countries, and they reach the conclusion that this support promotes exports to high and middle-income countries instead of politically and commercially unstable lowincome countries. Egger and Url (2006) concentrate on public export guarantees in Austria between 1996 and 2002. They show that public export credit guarantees have less than a proportional positive effect on international trade volume. These guarantees predominantly affect the country structure of foreign trade but leave industry specialization almost unchanged. Moser, Nestmann and Wedow (2008) analyze the influence of export promotion on exports in Germany between 1991 and 2003. They conclude that export promotion has a positive influence on exports. They also show that the lower the political risk of the target country, the more exports the target country gets.

This paper's points of departure are the static and dynamic models of Moser, Nestmann and Wedow (2008). In applying their models to the data of the Czech Export Bank, we find some statistical evidence on the effectiveness of public export credit support. A possible weakness of the econometric model of Moser, Nestmann and Wedow (2008) (and all other models mentioned in the previous paragraph) may be the assumption of equal importance of all observations in their sample. This assumption is relaxed by applying robust statistic methods. When the robust Least Trimmed Squares (LTS) approach to identifying influential data points is implemented, we conclude that the gravity equation is the appropriate model for the analysis of the export flows and government support in the case of a transition country such as the Czech Republic. The LTS approach also confirms that credit support increases exports, but distance is still a more influential factor.

The remainder of this paper is organized as follows: In the second section, we provide an overview of Czech export promotion. In the third section we describe the data and the estimation strategy. The fourth section presents the results. In section 5 we discuss the possibility of using robust estimations and the final section concludes the paper. 


\section{Czech Export Promotion}

Up to the beginning of economic transition in 1990, Czech exports were primarily oriented to the Soviet Union and other socialist or Soviet Block sympathizing countries. The Czech Republic (together with the German Democratic Republic) was the country with the highest standards of living and the best technological traditions in the whole Soviet Block. This relative position determined its trade patterns. The release from political dependence on the Soviet Union in 1990 led to the break-up of Comecon and to a strong trade reorientation to Western markets. In the case of the Czech Republic, trade flows were also influenced by the break-up of Czechoslovakia and the establishment of independent Czech and Slovak Republics in 1993.

Between 1993 and 2001, Czech exports to EU countries increased from USD 6.7 billion to USD 22.9 billion. This is an annual growth of $16.2 \%$, while exports to countries outside the EU grew only by $2 \%$ yearly. At the beginning of the economic transition the Czech balance of payments kept worsening, but between 1997 and 2008 the balance of payment improved. The year 1997 is an important benchmark since it was the year of major changes in the Czech economy and politics. The main factors promoting the growth of exports after 1997 were foreign direct investment growth and extensive privatization of major state-owned firms in financial and real sectors. In the following years the deficit of the Czech balance of payment was declining and in 2004 the balance of payment achieved a surplus. The annual exports of the CR has risen from USD 14.4 billion in 1993 to USD 65.7 billion in 2007. The most important changes are connected with machine production, electricity equipment and motor vehicle industries. The balance of these industries changed from that of a of deficit into a relatively significant surplus. Moreover, these industries represent the biggest share of total foreign trade.

After the few initial years of economic transition when the emphasis was on dismantling the old system of centrally planned trade and introducing free trading possibilities, Czechoslovakia and the Czech Republic started to introduce a new 
export promotion system established according to Western standards. In 1992 the Export Guarantee and Insurance Corporation (EGIC) was established. In 1995 it was followed by the Czech Export Bank (CEB) and the export support system was completed in 1997 by the creation of the agency Czech Trade.

The Export Guarantee and Insurance Corporation (EGIC) was founded as a state-owned export credit agency insuring credits connected with exports of goods and services from the Czech Republic against political and commercial risks. EGIC as part of the state export support program provides insurance services to all exporters of Czech goods irrespective of their size, legal form and volume of insured exports.

EGIC offers long-term insurance of commercial and territorial risks. Since 2005 short-term credit insurance is covered by its subsidiary Commercial Credit Insurance Company of EGIC. Commercial risk of exports is characterized as such risk which is subject to influence from the credit recipient's behavior. This risk results from the debtor's financial and economic situation and includes factors such as nonpayment of debit, delay of payment due to insolvency or declaration of insolvency proceedings on the holdings of a firm. The territorial risk derives from the political, macroeconomic and financial situation of a debtor country. From the point of view of foreign buyers such risks are out of their control. These risks include, for example, political events such as wars, revolutions, revolts, strikes, problems with the transfer of finance to lenders, political or administrative procedures that restrain payment, or natural catastrophes. EGIC abides by the common classification of territorial risks according to the OECD Consensus, which classifies countries into 8 categories according to the degree of territorial risk. The lowest risk is represented by the group marked as "0" where essentially no territorial risk exists (including USA, Japan, the industrialized economies of EU and, as of 2008, the Czech Republic). On the other hand the highest territorial risk is represented by the number "7" group (including Lebanon, Nepal, Ecuador etc).

The other Czech export credit agency, Czech Export Bank (CEB), is a spe- 
cialized banking institution whose mission is to provide state support for exports through the provision and financing of export credits and other services connected with exports. CEB thus supplements the services offered by the domestic banking system by financing export operations that require long-term financing at interest rates and in volumes that are not available to exporters on the banking market under current domestic conditions. This allows Czech exporters to compete on international markets under conditions comparable to those enjoyed by their main foreign competitors. The government support of CEB exists in three different forms (government contribution to basic capital of $\mathrm{CEB}$, state guarantees of provided export credit, subsidies from the state budget for coverage of differences between accepted and provided credits).

CEB is a member of a working group for export credits, OECD, and is obliged to follow international rules for government-supported export financing. These rules include, e.g., environmental impact assessment, strict requirements within the framework of anti-corruption efforts and rules of the IMF on funding exports to low-income countries. The volume of concluded contracts in any single year is influenced by macro-economic development both in the Czech Republic and abroad. Quite naturally, in the years of economic growth the volume of concluded contract has been higher. The exchange rate has an active role too. CEB offers a wide variety of credits and supporting services for export promotion. The most frequent type of credit are export buyer credit, direct export supplier credit or refinancing of export credit.

The youngest of the Czech export promotion institutions, Czech Trade, was founded in 1997 by the Czech Ministry of Industry and Trade. Since 1999, Czech Trade has built a network of its own foreign agencies. The main purpose of Czech Trade agency is to assist Czech companies with their entry into foreign markets, to provide information about these markets, information about the conditions of entry into these markets, and information about demand, competition and price levels. Czech Trade also supports the specialized Euroservice department whose principle 


\begin{tabular}{|c|c|c|c|c|c|c|c|c|c|c|c|c|}
\hline & \multicolumn{12}{|c|}{ Export (share of total export / absolute values) } \\
\hline year & \multicolumn{2}{|c|}{$\begin{array}{l}\text { Developed } \\
\text { countries }\end{array}$} & \multicolumn{2}{|c|}{$\begin{array}{c}\text { European } \\
\text { developing } \\
\text { countries }\end{array}$} & \multicolumn{2}{|c|}{$\begin{array}{c}\text { Commonwealth } \\
\text { of Independent } \\
\text { States }\end{array}$} & \multicolumn{2}{|c|}{ America } & \multicolumn{2}{|c|}{ Africa } & \multicolumn{2}{|c|}{ Asia } \\
\hline 1996 & 14322 & $65.2 \%$ & 5446 & $24.8 \%$ & 1079 & $4.9 \%$ & 164 & $0.7 \%$ & 333 & $1.5 \%$ & 647 & $2.9 \%$ \\
\hline 1997 & 14738 & $66.4 \%$ & 5382 & $24.2 \%$ & 1157 & $5.2 \%$ & 149 & $0.8 \%$ & 166 & $0.7 \%$ & 610 & $2.7 \%$ \\
\hline 1998 & 17964 & $70.1 \%$ & 5676 & $22.1 \%$ & 1042 & $4.1 \%$ & 158 & $0.6 \%$ & 185 & $0.7 \%$ & 602 & $2.3 \%$ \\
\hline 1999 & 19392 & $75.1 \%$ & 4987 & $19.3 \%$ & 643 & $2.5 \%$ & 121 & $0.5 \%$ & 163 & $0.6 \%$ & 518 & $2.0 \%$ \\
\hline 2000 & 21825 & $75.6 \%$ & 5282 & $18.3 \%$ & 725 & $2.5 \%$ & 159 & $0.6 \%$ & 140 & $0.5 \%$ & 732 & $2.5 \%$ \\
\hline 2001 & 25103 & $75.2 \%$ & 6104 & $18.3 \%$ & 850 & $2.5 \%$ & 188 & $0.6 \%$ & 164 & $0.5 \%$ & 951 & $2.9 \%$ \\
\hline 2002 & 28397 & $78.3 \%$ & 6962 & $18.4 \%$ & 892 & $2.4 \%$ & 182 & $0.5 \%$ & 192 & $0.5 \%$ & 981 & $2.6 \%$ \\
\hline 2003 & 36667 & $76.0 \%$ & 8879 & $18.4 \%$ & 1001 & $2.1 \%$ & 190 & $0.4 \%$ & 220 & $0.5 \%$ & 1301 & $2.7 \%$ \\
\hline 2004 & 49343 & $74.0 \%$ & 13137 & $13.3 \%$ & 1637 & $2.5 \%$ & 313 & $0.5 \%$ & 343 & $0.5 \%$ & 1907 & $2.9 \%$ \\
\hline 2005 & 56136 & $72.2 \%$ & 15933 & $20.5 \%$ & 2455 & $3.2 \%$ & 463 & $0.6 \%$ & 549 & $0.7 \%$ & 2247 & $2.9 \%$ \\
\hline 2006 & 67881 & $71.7 \%$ & 19881 & $20.1 \%$ & 3243 & $3.4 \%$ & 532 & $0.6 \%$ & 695 & $0.7 \%$ & 2450 & $2.6 \%$ \\
\hline 2007 & 85554 & $70.2 \%$ & 26687 & $21.9 \%$ & 4548 & $3.7 \%$ & 714 & $0.6 \%$ & 915 & $0.8 \%$ & 3397 & $2.8 \%$ \\
\hline 2008 & 99111 & $68.8 \%$ & 32847 & $22.8 \%$ & 6248 & $4.3 \%$ & 801 & $0.6 \%$ & 1104 & $0.8 \%$ & 4001 & $2.8 \%$ \\
\hline
\end{tabular}

Table 1: Czech exports by regions. For each group of countries, figures in the first column are the percentage of total exports; figures in the second column are absolute values (in USD millions).

task is dissemination of information about the EU and about access to help and assistance from EU resources. Czech Trade also organizes export seminars and has established the Export Academy, which is one of the tools of the Czech Export Strategy.

The whole system of export promotion is summarized in a governmental document named Export Strategy of the Czech Republic. This strategy is inspired by the systems of export promotions in countries of the EU and USA and it reflects the demands of Czech firms which have export-related interests as well. The Export Strategy for the period 2006-2010 is part of the economic policy of the Czech government and is related to the Czech Strategy of Economic Growth and the Export Strategy of the Czech Republic for the period 2003-2006. The basic goal of the strategy is the improvement of the country's image, the increase of competitiveness of Czech enterprises and their success on foreign markets, and the assertion of economic and business goals of the Czech Republic abroad.

The evolution and territorial structure of Czech export and export promotion provided by CEB is covered in Tables 1 and 2. The data in the tables show that 


\begin{tabular}{|l|ll|ll|l|l|l|l|ll|ll|}
\hline \hline & \multicolumn{8}{|c|}{ Guarantees (share of total guarantees / absolute values) } \\
\hline year & $\begin{array}{c}\text { Developed } \\
\text { countries }\end{array}$ & $\begin{array}{c}\text { European } \\
\text { developing } \\
\text { countries }\end{array}$ & $\begin{array}{c}\text { Commonwealth } \\
\text { of Independent } \\
\text { States }\end{array}$ & America & Africa & & Asia \\
\hline 1996 & 0 & $0 \%$ & 196 & $61.4 \%$ & 0 & $0 \%$ & 0 & $0 \%$ & 57 & $17.9 \%$ & 66 & $20.7 \%$ \\
1997 & 22 & $16.3 \%$ & 1.5 & $1.1 \%$ & 2.24 & $1.7 \%$ & 0 & $0 \%$ & 0.99 & $0.7 \%$ & 108 & $80 \%$ \\
1998 & 6 & $7 \%$ & 0.09 & $0.1 \%$ & 11.6 & $13.5 \%$ & 0 & $0 \%$ & 4.99 & $5.8 \%$ & 63 & $73.5 \%$ \\
1999 & 172 & $35.8 \%$ & 9.57 & $2.0 \%$ & 89 & $18.5 \%$ & 1.3 & $0.3 \%$ & 0.79 & $0.2 \%$ & 208 & $43.3 \%$ \\
2000 & 178 & $32.5 \%$ & 103 & $18.8 \%$ & 99 & $18.1 \%$ & 0.4 & $0.1 \%$ & 0 & $0 \%$ & 167 & $30.5 \%$ \\
2001 & 141 & $19.4 \%$ & 120 & $16.5 \%$ & 249 & $34.2 \%$ & 0 & $0 \%$ & 0 & $0 \%$ & 218 & $30 \%$ \\
2002 & 208 & $43.4 \%$ & 102 & $21.3 \%$ & 4 & $0.8 \%$ & 0.3 & $0.1 \%$ & 51.1 & $10.7 \%$ & 114 & $23.8 \%$ \\
2003 & 20 & $5.8 \%$ & 98 & $28.2 \%$ & 11.6 & $3.3 \%$ & 0.2 & $0.1 \%$ & 0 & $0 \%$ & 217 & $62.3 \%$ \\
2004 & 195 & $18.9 \%$ & 163 & $15.8 \%$ & 50 & $4.8 \%$ & 0 & $0 \%$ & & $0 \%$ & 626 & $60.5 \%$ \\
2005 & 449 & $56.1 \%$ & 40 & $5.0 \%$ & 278 & $34.8 \%$ & 0 & $0 \%$ & 0.08 & $0 \%$ & 33 & $4.1 \%$ \\
2006 & 45 & $5.1 \%$ & 78 & $8.9 \%$ & 627 & $71.2 \%$ & 0 & $0 \%$ & 0 & $0 \%$ & 131 & $14.9 \%$ \\
2007 & 69 & $7.3 \%$ & 9 & $1.0 \%$ & 618 & $65.8 \%$ & 0 & $0 \%$ & 0 & $0 \%$ & 243 & $25.9 \%$ \\
2008 & 20 & $2.1 \%$ & 266 & $28.2 \%$ & 614 & $65.0 \%$ & 0 & $0 \%$ & 0 & $0 \%$ & 44 & $4.7 \%$ \\
\hline \hline
\end{tabular}

Table 2: Export promotion according to CEB. For each group of countries, figures in the first column are the percentage of total guarantees; figures in the second column are absolute values (in USD millions).

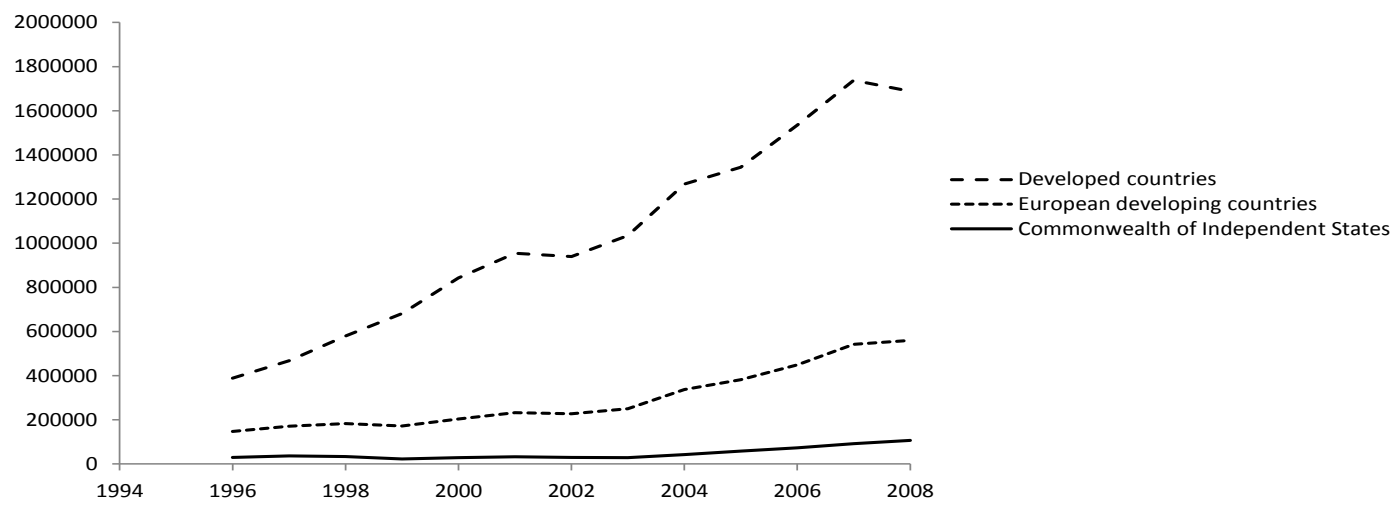

Figure 1: Export according to regions, Czech Republic, millions USD (the Czech Statistical Office) 


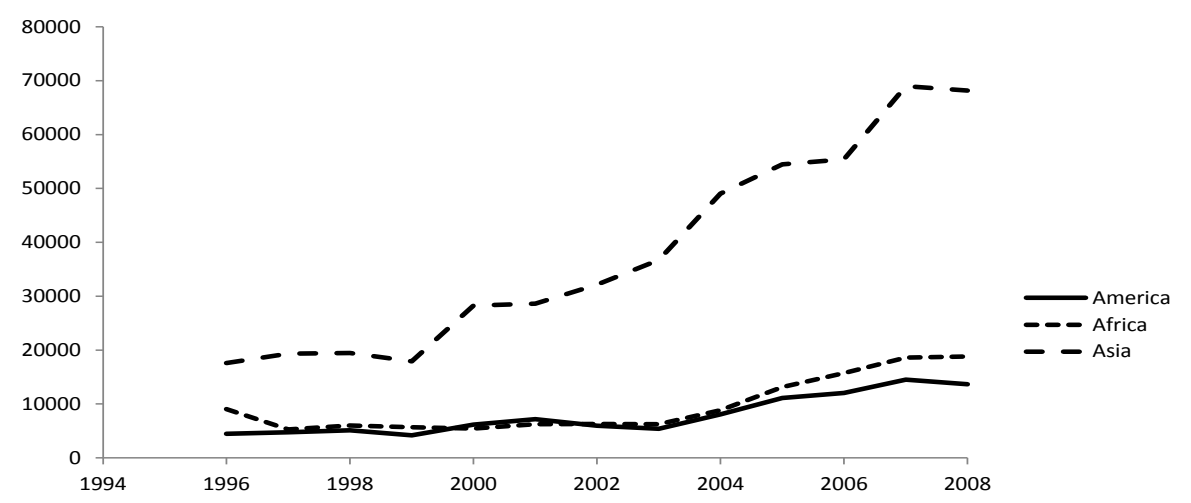

Figure 2: Export according to regions, Czech Republic, millions USD (the Czech Statistical Office)

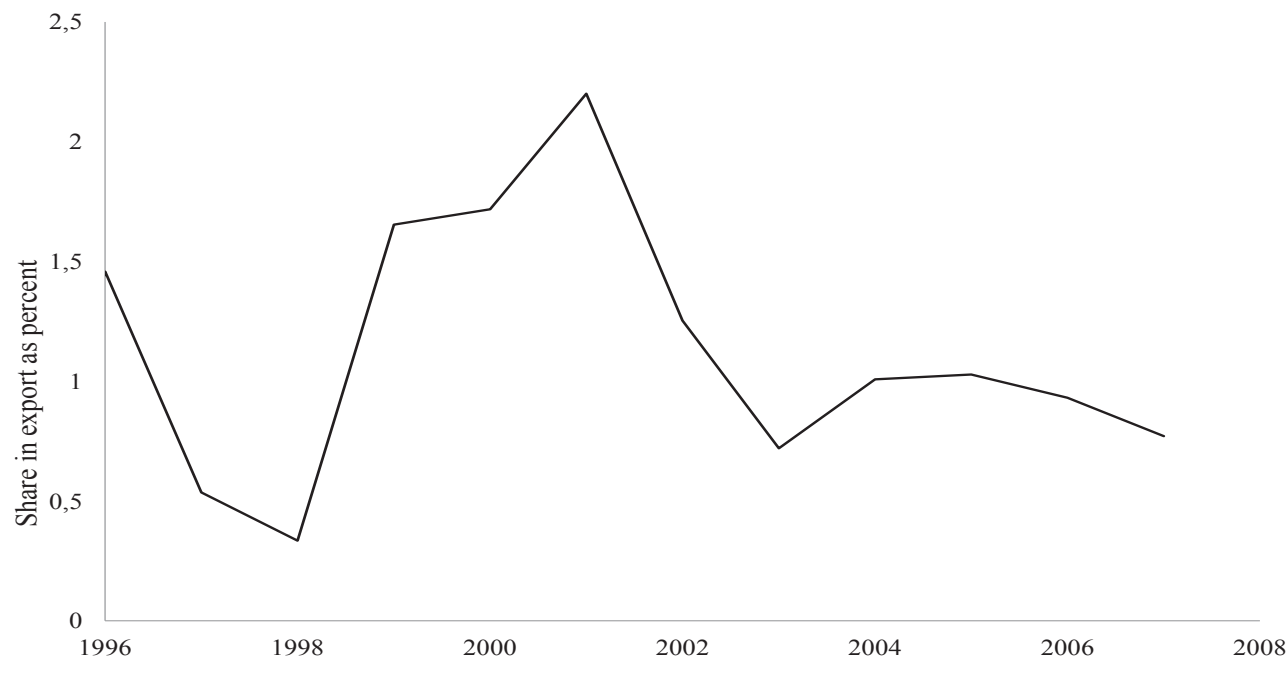

Figure 3: Export Guarantees (Newly Covered Business) as a Share of Goods Export, Czech Republic 
Czech export goes mainly to developed countries - in 2008 the share of export into industrial countries reached almost $70 \%$ of total exports. On the other hand, export promotion is concentrated more on developing countries' exports. The share of export promotion out of total exports in developed countries is on average only $0.33 \%$, while the share of export promotion out of total exports in developing countries is $3.14 \%$. The other important destination of the Czech Republic is Central and Eastern Europe (e.g., Slovakia, Poland and Hungary). The reason is the region's recent economic development as well as these countries' geographic proximity and historical ties. Export promotion leads mainly to the countries of The Commonwealth of Independent States where Russia has the major share. The classification of countries into regions can be found in the Appendix (Table 8). Figures 1 and 2 show Czech exports over time according to six different regions. It is clear that the largest volume of exports is connected with more developing countries where the distance from the Czech Republic is not too great. Figure 3 shows the ratio of guarantees over exports for the Czech Republic. In comparison with some other countries (i.e., Austria by Egger and Url, 2006) this ratio is not high and moves between $0.5 \%$ and $2.5 \%$.

\section{Data and Methodology of Estimation}

We use an unbalanced panel of 160 countries between 1996 and 2008. The relatively short time series with respect to the relatively large number of countries in our sample must be taken into account. However, panel data are appropriate for our study because cross-sectional data would make assessments of different changes in time impossible. The time series aspect of the analysis is very important. Economies in individual countries can go through comprehensive changes and reforms during the time periods and new exports can be a function of past exports. However, the cross-sectional aspect of the present study is also important. The inclusion of more countries into the data is hoped to introduce more heterogeneity. 
The data used in this paper come from various sources: the Czech Statistical Office (export), the Czech Export Bank (export promotion), the International Monetary Fund (GDP, population), World Development Indicators 2007 (gross fixed capital formation, manufacturing imports), the Euromoney journal (political risk). Variable Distance is calculated as a distance between Prague and the capital city of the importing country according to http://www.timeanddate.com/worldclock/distance.html.

\subsection{The Gravity Model and Description of Variables}

In this paper, the approach of Egger and Url (2006) and Moser, Nestmann and Wedow (2008) is followed. Parameters of the following modified gravity model are estimated:

$$
\begin{aligned}
\ln \left(\text { Exports }_{i t}\right)= & \alpha_{0}+\alpha_{1} \ln \left(\text { guarantees }_{i t}\right)+\alpha_{2} \ln \left(G D P_{i t}\right)+\alpha_{3} \ln \left(\text { dist }_{i}\right)+ \\
& +\alpha_{4} \ln \left(\text { pop }_{i t}\right)+\alpha_{5} \ln \left(\text { risk }_{i t}\right)+\alpha_{6} \ln \left(\text { GFCF }_{i t}\right)+ \\
& +\alpha_{7} \ln \left(M I_{i t}\right)+\varepsilon_{i t}
\end{aligned}
$$

Descriptive statistics (mean, standard deviation, minimum, maximum and number of observation) are summarized in Table 3. The measure of interdependence is described in the correlation matrix in the Appendix (Table 9).

According to Egger and Url (2006) we suppose that $\varepsilon_{i t}$ in Equation 1 is a random error term which consists of two parts. Therefore we can write

$$
\varepsilon_{i t}=\mu_{i}+u_{i t}
$$

where $\mu_{i}$ is an unobserved country-specific effect and $u_{i t}$ is an error term with zero mean and constant variance.

The dependent variable is a logarithm of real exports from the Czech Republic to country $i$ in year $t$ in CZK real prices. The explanatory variables are as follows. 


\begin{tabular}{|llllll|}
\hline \hline & Mean & $\begin{array}{l}\text { Standard } \\
\text { deviation }\end{array}$ & Minimum & Maximum & $\begin{array}{l}\text { Number } \\
\text { of obs. }\end{array}$ \\
\hline Export (mill. USD) & 333 & 1750 & 0.000032 & 35400 & 2043 \\
Guarantees (mil. USD) & 3.28 & 23.1 & 0 & 454 & 2043 \\
GDP (bill. USD) & 233 & 941 & 0.000014 & 11500 & 2043 \\
$\begin{array}{l}\text { Population (mill.) } \\
\text { Distance (km) }\end{array}$ & 38.48 & 136.68 & 0,071 & 1328 & 2043 \\
$\begin{array}{l}\text { Gross fixed capital formation } \\
\text { (\% GDP) }\end{array}$ & 5477 & 3638.95 & 247 & 18197 & 2043 \\
$\begin{array}{l}\text { Manufacturing Imports } \\
\text { (\% of imports) }\end{array}$ & 68.64 & 11.24 & 16,30 & 92 & 1725 \\
Political risk & & & & & 63 \\
\hline \hline
\end{tabular}

Table 3: Descriptive statistics. Figures are reported in US Dollars (source of exchange rate: $\mathrm{CNB}$ )

$\ln \left(\right.$ guarantees $\left._{i t}\right)$ is a logarithm of real newly granted guarantees by CEB for country $i$ in year $t$ in CZK real prices. This variable describes the sum of all contracts across all products of CEB (different types of loans, guarantees, etc). The value of this variable is zero if there are no contracts made. For these cases the logarithmic transformation does not work because logarithm of zero is undefined. A common practice is to remove zero observations out of the data set. On the other hand, by removing observations with the value of zero, the number of remaining observations would decrease substantially. Another common practice is to add a small value to the data before logarithmic transformation. However, different values can lead to different results (Jongman et al., 2002). Since our non-zero values are very large, we shall estimate three different models with three different constants (0.1, 0.5 and 1 according to Porojan (2001) and Burger, Oort and Linders (2009)), and we will test the hypothesis as to whether the coefficients are equal in different regressions. This variable is crucial for our analysis. The aim of the analysis is to test whether the guarantees provided by CEB support Czech exports. The main motivation for CEB guarantees is the realization of those effective exports which could not be carried out without the support. This variable is expected to be significant with the positive sign of estimated coefficient $\alpha_{1}$. 
$\ln \left(G D P_{i t}\right)$ is a logarithm of real GDP of country $i$ in year $t$ in CZK real prices. This variable is used as a proxy for market size. We assume that the larger the country is, the higher is its export demand. Therefore we expect a positive sign of estimated coefficient $\alpha_{2}$.

$\ln \left(\right.$ dist $\left._{i}\right)$ is a logarithm of distance between the Czech Republic and country $i$. This variable is used as a proxy for transportation as well as information costs. According to Moser, Nestmann and Wedow (2008) the growing distance leads to the decrease of correlation between foreign and Czech business cycles and this variable is expected to be significant with a negative sign of estimated coefficient $\alpha_{3}$.

$\ln \left(\right.$ pop $\left._{i t}\right)$ is a logarithm of population in country $i$ in year $t$. The higher the population, the higher is the demand for exports. Thus we expect the significant variable with a positive sign of estimated coefficient $\alpha_{4}$.

$\ln \left(\right.$ risk $\left._{i t}\right)$ is the logarithm of the political risk index in country $i$ in year $t$. The value of political risk moves between 25 points (=minimum risk) and 0 points (=maximum risk). The source of our political risk index is Euromoney Country Risk index, which includes political risk as one of its components. Euromoney political risk covers major political factors that may influence the risk of investing in a given country. It is constructed as an average of following six indicators: corruption (ranging from no corruption up to endemical corruption which is a serious drag on stability and a major contributor of political risk); government non-payments/ non-repatriation, which is a measure of the risk government policies and actions pose to financial transfers; government stability (ranging from an extremely stable government up to the country which has no functioning government and has already become a failed state); institutional risk, which is a measure of independence and efficiency of state institutions; regulatory and policy environment (ranging from extremely consistent, well-enforced regulatory environment and benevolent govern- 
ment policies up to the situation where no regulatory environment exists). All these indicators are evaluated by a large number of individual experts and the final value of the political risk index is obtained as an average of those individual evaluations. Countries with higher political risk receive ceteris paribus less exports. The higher the value of variable political risk, the greater are exports to the country. Thus we expect a positive sign of estimated coefficient $\alpha_{5}$. In two cases the value of this variable is zero. Since corresponding values of Manufacturing imports are missing, these two observations are not included into the data set.

There are also two additional explanatory variables:

$\ln \left(G F C F_{i t}\right)$ is the logarithm of a country's gross fixed capital formation to GDP, the so called rate of investment. This variable is measured as total value of additions to fixed assets purchased by business, government and households minus disposals of fixed assets sold off or scrapped. Since the value for 2008 is missing, we will use time series merely between 1996 and 2007. We expect a positive sign for this variable.

$\ln \left(M I_{i t}\right)$ is a logarithm of a country's share of manufacturing imports in overall imports. We postulate the hypothesis that countries with a similar factor endowment receive more exports. Since we do not include human capital and physical capital stocks variables, variable manufacturing imports serves as a proxy for a country's relative factor endowment. The higher is the physical capital per labor and human capital per labor variables, the higher is the share of industry imports. Thus we expect a positive sign for this variable.

\subsection{Methodology of Estimation}

Firstly, we use a standard fixed effect model as a benchmark and estimate a static regression model. The fixed effects model is more appropriate than the random effects model because our panel contains most of the countries and not just a random sample of them (Judson and Owen, 1996). Moreover, the Hausman test rejects the 
random effect model (Hausman, 1978). As the next step we assume that past values of export can be expressed as the process of partial stock adjustment. Therefore, dynamic estimation is used which can reflect the long- run impact and the influence of past values more appropriately. We suppose it takes time for export to adjust to the equilibrium or desired level:

$$
\begin{aligned}
\ln \left(\text { Export }_{i t}\right)-\ln \left(\text { Exports }_{i t-1}\right) & =\beta\left[\ln \left(\text { Exports }_{i t}^{*}\right)-\ln \left(\text { Export }_{i t-1}\right)\right] \\
\ln \left(\text { Exports }_{i t}\right) & =(1-\beta) \ln \left(\text { Exports }_{i t-1}\right)+\beta \ln \left(\text { Export }_{i t}^{*}\right)(2)
\end{aligned}
$$

where $\ln \left(\right.$ Exports $\left._{i t}^{*}\right)$ is the equilibrium level of the stock of exports and $\beta$ is less than 1 for stability. The equilibrium level is determined by $X_{i t}$, a vector of $k$ explanatory variables that has been described earlier:

$$
\ln \left(\text { Exports }_{i t}^{*}\right)=\gamma X_{i t}+e_{i t},
$$

where $e_{i t}$ is a disturbance term including two orthogonal components: the country specific effects and idiosyncratic shocks, $E\left[e_{i t}\right]=0$. By reformulating model $(2)$ and model (3) we obtain:

$$
\begin{aligned}
\ln \left(\text { Exports }_{i t}\right) & =\delta \ln \left(\text { Exports }_{i t-1}\right)+\lambda X_{i t}+\varepsilon_{i t} \\
\varepsilon_{i t} & =\mu_{i}+u_{i t} \\
E\left[\mu_{i}\right] & =E\left[u_{i t}\right]=E\left[\mu_{i} u_{i t}\right]=0
\end{aligned}
$$

where $\delta=1-\beta$ and $\lambda=\beta \cdot \gamma$ are coefficients to be estimated, $\gamma$ is a vector of dimension $1 \times k, \varepsilon_{i t}=\beta \cdot e_{i t}, \mu_{i}$ is the country-specific effect. Since model (4) estimated by OLS is inconsistent (because $\ln \left(\right.$ Exports $\left._{i t-1}\right)$ and $\mu_{i}$ are correlated), 
we estimate the model in first differences:

$$
\Delta \ln \left(\text { Exports }_{i t}\right)=\delta \Delta \ln \left(\text { Exports }_{i t-1}\right)+\lambda \Delta X_{i t}+\Delta \varepsilon_{i t}
$$

and the country-specific effect will disappear. However, $\Delta \ln \left(\operatorname{Exp}_{i t-1}\right)$ and $\Delta \varepsilon_{i t}$ are still correlated. Therefore, we use the generalized method of moments (GMM). The Difference (DIFF) and System (SYS) GMM estimators are designed for panel analysis. They use several assumptions about the data-generating process. DIFF-GMM, proposed by Arellano and Bond (1991), is based on first-differenced variables, thus eliminating the country-specific effect, and instrumenting all potentially endogenous variables with their own suitably lagged levels. However, this estimator has been found to behave poorly in small samples where it is biased. It also has poor behavior in unbalanced panels where one can construct data sets that completely disappear in first differences and it is not possible to include time invariant variables into the model. The SYS-GMM, proposed by Arellano and Bover (1995) and Blundell and Bond (1998) combines the standard set of equations in first differences with suitably lagged levels as instruments, with an additional set of equations in levels with suitably lagged first-differences as instruments (Roodman, 2009). The validity of additional instruments can be tested using standard Sargan or Hansen tests of over-identifying restrictions or using Hausman comparisons between the DIFF and SYS GMM results (Arellano and Bond, 1991). The $R^{2}$ for the GMM is a pseudo $R^{2}$ computed by regressing exports on its predicted value. For stationarity verification we apply the LLC unit root test (Levin, Lin and Chu, 2002,) which is modified for panel data and is derived from the Dickey-Fuller test.

\section{Empirical Results}

This section presents the results of the estimation. Table 4 presents the estimates of the static model by pure fixed effects and the estimates of the dynamic model. Unless noted otherwise, results are compared with the $5 \%$ significance level. Zero 
values are replaced by number 1 . Sensitivity analyses where zero values are replaced by constant 0.1 or 0.5 can be found in the Appendix (Table 10). The coefficients estimated for the data where zero values are replaced by constants 0.1 and 0.5 are equal to the coefficients estimated for the data where these values are replaced by 1.

OLS of the log-linear model can be biased and inconsistent; log-linearization of the error term can change the property of error term and can be the cause of heteroskedasticity. The expected value of the log-linearized equation would be

$$
\begin{aligned}
E\left[\ln \left(\text { Export }_{i t}\right)\right] & =E\left[\alpha_{0}+\alpha_{1} \ln \left(\text { guarantees }_{i t}\right)+\ldots+\ln \left(e_{i t}\right)\right]= \\
& =E\left[\alpha_{0}\right]+\alpha_{1} E\left[\ln \left(\text { guarantees }_{i t}\right]+\ldots+E\left[\ln \left(e_{i t}\right)\right]\right.
\end{aligned}
$$

(where $\left.\ln \left(e_{i t}\right)=\varepsilon_{i t}\right)$. According to Jensen's inequality, $\ln E\left[e_{i t}\right] \neq E\left[\ln \left(e_{i t}\right)\right]$. Thus, OLS estimation can result in misleading estimates and values of statistics. Silva and Tenreyro (2006) recommend estimating the model in levels, instead of taking logarithms. This solves the problem of zero observations. There are two different solutions: NLS (Nonlinear Least Squares) or PPML (Poisson Pseudo Maximum Likelihood). The second is preferred. It is customary to specify E[Exports $\left.s_{i t} \mid x\right]=$ $\exp \left(x_{i t} \beta\right)$ and $\beta$ can be estimated by maximum likelihood. The estimator is defined by

$$
\hat{\beta}=\arg \max \sum_{j=1}^{K}\left[\operatorname{Exports}_{j}\left(x_{j} b\right)-\exp \left(x_{j} b\right)\right]
$$

where $K$ is the number of observations. This is the pseudo-maximum likelihood result first noted by by Gourieroux, Monfort and Trognon (1984). This estimator is consistent even if the conditional variance is not well specified. The data need not be Poisson and $x$ vector need not have integer values. We present the estimated coefficients of static model by PPML in Table 10. The significance of parameters obtained by OLS (fixed effects) is comparable to the ones obtained by PPML and conclusions are similar. A robust check by PPML confirmed that our approach 


\begin{tabular}{|ccc|}
\hline \hline & fixed effects & system GMM \\
\hline $\ln \left(\right.$ Export $\left._{t-1}\right)$ & - & $0.503^{* * *}(0.079)$ \\
$\ln \left(\right.$ guarantee $\left._{i t}\right)$ & $0.011^{* * *}(0.003)$ & $0.032^{*}(0.017)$ \\
$\ln \left(\right.$ GDP $\left._{i t}\right)$ & $0.230^{* * *}(0.060)$ & $0.270^{* *}(0.132)$ \\
$\ln \left(\right.$ dist $\left._{i}\right)$ & $-4.408^{* * *}(1.075)$ & $-0.694^{* * *}(0.134)$ \\
$\ln \left(\right.$ pop $\left._{i t}\right)$ & $2.956^{* * *}(0.457)$ & $0.214(0.169)$ \\
$\ln \left(\right.$ GFC $\left._{i t}\right)$ & $0.426^{* * *}(0.139)$ & $1.090^{* *}(0.439)$ \\
$\ln \left(\right.$ M $\left._{i t}\right)$ & $-0.368(0.254)$ & $0.199(0.511)$ \\
$\ln \left(\right.$ ris $\left._{i t}\right)$ & $0.187^{*}(0.112)$ & $0.176(0.229)$ \\
Number of obs. & 1429 & 1237 \\
Number of groups & 145 & 137 \\
Adjusted $/$ Pseudo $R^{2}$ & 0.950 & 0.19 \\
Hansen test $(p$-value $)$ & - & 0.067 \\
A-B AR $(1)$ (p-value $)$ & - & 0.000 \\
A-B AR $(2)$ (p-value $)$ & - & 0.640 \\
LLC test $(p$-value $)$ & - & 0.000 \\
\hline \hline
\end{tabular}

Table 4: Estimation of static and dynamic models. Notes: ${ }^{*}$ significant at $10 \%$; $* *$ significant at $5 \%$; ${ }^{* * *}$ significant at $1 \%$. Robust (White heteroskedastic consistent) standard errors in brackets. Specific effects dummies are not reported. Hausman test rejects the random effects model. Response variable: logarithm of export. All variables are in logarithm. Zero values replaced by number 1 .

of replacing zero values does not distort the estimated parameters and qualitative results of our model. Variance inflation factor (VIF, O'Brien, 2007) does not suggest any problems with collinearity.

Firstly, we comment on the estimates of the static model. Since the coefficient of determination is about $95 \%$, we see that the quality of the model from the point of view of data variability is good. R-squared from DVM regression will usually be artificially high since we have so many dummy variables in the model. However, R-squared is still a valid measure of variation of the dependent variable that is explained by regressors (including dummies), and it can be used for regular testing procedures. Another good measure of explanatory power is the F-test of the model. In our case R-squared is $95 \%$, so we can conclude that the quality of whole model from the point of view of data variability is good. On the other hand it is necesary to mention that fixed effects absorb a significant part of the variation in the dependent variable. Results of the F-test suggest that quality of our model is good.

The effect of guarantees on export is positive and is statistically significant. This 
result supports our hypothesis that higher guarantees lead ceteris paribus to higher exports. The variable describing GDP is significant and the parameter is positive. This is consistent with our expectations. The higher is the GDP of the importing country, the more exports it gets. Other significant and positive variables are gross fixed capital formation and population. The volume of exports is positively influenced by the volume of population. The distance variable coefficient is significant and negative. This means that higher exports are associated with geographically close countries and that transportation costs are important in Czech international trade. On the other hand, variable manufacturing imports is not significant. We also included a proxy variable describing political risk and this variable is significant in the static model at the $10 \%$ level. This result is not conclusive enough and it does not correspond with the importance usually given to political risk in discussions on international trade and its government support.

As has been mentioned, dynamic models allow better understanding of the dynamic adjustment. If the data generating process is dynamic, estimates for both short and long-run effects will be biased (Egger and Pfaffermayer, 2005 and Moser, Nestmann and Wedow, 2008). However, if we test for agglomeration effect and relate current values of the response variable to the past value of the response variable along with other explanatory variables, the OLS estimates of fixed effects estimates will be biased (Nickell, 1981, Baltagi, 1998 and Bond, 2002). Therefore, we will use an instrumental variable approach described in the previous section. Following Blundell and Bond (1998), we will use the SYS-GMM estimator, which uses lagged levels as instruments in the difference equation and additionally first differences for the level equation. Moreover, the use of the SYS-GMM is also partly driven by the high persistence in the export series (Moser, Nestmann and Wedow, 2008). Blundell and Bond (1998) show that a high persistence in the series leads to weak instruments in the DIFF-GMM estimator and can thus be subject to bias. The use of additional instruments under the SYS-GMM results in much smaller biases and greater precision in the estimates. 
In Table 4 we present the results of System GMM estimates for our dynamic model. We can see that the estimated coefficient of the lagged variable is significant, positive and less than 1 . Thus we can conclude that the data generating process is really dynamic. We check for the validity of instruments by several tests. Firstly, the Hansen test rejects the null hypothesis of over- identification of parameters (Hansen, 1982). This result suggests that there are no problems with endogeneity in our empirical model and the instruments are valid. Moreover, the Arellano-Bond $\mathrm{AR}(2)$ test does not suggest second-order serial correlation. The LLC test rejects the hypothesis of unit root (nonstationarity). Pseudo R-squared is low, but it is not necessarily an indictment of our model because of the problematic dataset.

The guarantees variable is significant at the $10 \%$ level and positive. This means that guarantees have a positive impact on exports. We can express the estimated coefficient as an elasticity: a 1 percent increase in guarantees leads to a 0.064 percent increase in exports. (We are interested in coefficient $\gamma$ in model (3) which we compute from the parameters in model (4). This coefficient can be expressed as $\left.\gamma=\frac{\lambda}{\beta}=\frac{\lambda}{1-\delta}=\frac{0.032}{1-0.503}=0.064\right)$. We can compare this result with the short-run effect from the previous analysis. Coefficient estimated by fixed effects has the approximate value of 0.011 , which is less. Short-run effects are typically substantially lower than the one given. Most guarantees are granted for periods longer than one year (Moser, Nestmann and Wedow, 2008). Since we expected that guarantees should be a highly significant factor, this result obtained in the dynamic model is too inconclusive.

Commentary on the rest of the results is as follows. As in the previous analysis, variable distance is significant and negative. As compared with the static model, the population is not significant. Variable GDP is significant and positive. Czech exports are associated with countries with larger market size as measured by economic activity (GDP), not by the number of inhabitants. On the other hand, the negative coefficient of variable distance supports the fact that information costs or transaction costs are higher for countries far from the Czech Republic. Gross fixed 


\begin{tabular}{|c|c|}
\hline & system GMM \\
\hline $\ln \left(\right.$ Export $\left._{t-1}\right)$ & $0.478^{* * *}(0.076)$ \\
\hline $\ln \left(\right.$ guarantees $\left.{ }_{i t}\right)$ & $0.039^{* *}(0.018)$ \\
\hline $\ln \left(G D P_{i t}\right)$ & $0.439 * * *(0.167)$ \\
\hline $\ln \left(d_{i s t_{i}}\right)$ & $-0.913^{* * *}(0.199)$ \\
\hline $\ln \left(p o p_{i t}\right)$ & $0.081(0.199)$ \\
\hline $\ln \left(G F C F_{i t}\right)$ & $1.030 * *(0.457)$ \\
\hline $\ln \left(M I_{i t}\right)$ & $-0.232(0.496)$ \\
\hline $\ln \left(r i s k_{i t}\right)$ & $0.530 * *(0.275)$ \\
\hline Africa & $0.919 *(0.490)$ \\
\hline EasternEurope & $0.368^{* *}(0.156)$ \\
\hline LatinAmerica & $0.912 *(0.486)$ \\
\hline Number of obs. & 1237 \\
\hline Number of groups & 137 \\
\hline Adjusted/Pseudo $R^{2}$ & 0.21 \\
\hline Hansen test ( $p$-value) & 0.145 \\
\hline $\mathrm{A}-\mathrm{B} \operatorname{AR}(1)$ (p-value) & 0.000 \\
\hline $\mathrm{A}-\mathrm{B} \operatorname{AR}(2)(p$-value $)$ & 0.717 \\
\hline LLC test (p-value) & 0.000 \\
\hline
\end{tabular}

Table 5: Estimation of dynamic models with regional dummy variables. Notes: * significant at $10 \%$; ${ }^{* *}$ significant at $5 \%$; *** significant at $1 \%$. Robust (White heteroskedastic consistent) standard errors in brackets. Specific effects dummies are not reported. Response variable: logarithm of export. All variables are in logarithm (except dummy variables). Zero values replaced by number 1 .

capital formation is significant. The variables for manufacturing imports and political risk are not significant. These findings indicate that guarantees brings some positive results. However, from the statistical point we cannot answer the question of the influence of guarantees explicitly because of fluctuating p-values in both the static (significant at the 1\% level) and dynamic model (significant at the $10 \%$ level). Another problematic finding of our estimates is the low significance (or even insignificance) of some explanatory variables such as political risk or population.

\section{Robust Model}

The results obtained in the previous section are not conclusive: in two regression models we have reached p-values $1 \%$ and $10 \%$ for the variable describing guarantees, respectively. Estimates obtained by GMM in particular do not give sufficiently 
significant results. This result is at odds with theoretical models and some empirical evidence which suggest that guarantees should be a significant determinant of international trade. Thus we will test our model through a set of additional regressions.

Firstly, we include several regional dummy variables in our dynamic regression model, and we test whether different territories influence the amount of exports. We decided to test the influence of African countries, countries of Latin America and countries of Eastern Europe. Thus we constructed three different dummy variables which determine the location of the country. These variables are included into the dynamic regression model together with other variables and the model is estimated by SYS-GMM. We present these results in Table 5 . There is no problem with the test of validity of instruments and there is no endogeneity and no second-order serial correlation in the model. The lagged variable is significant and positive; the variable for guarantees is also significant and positive. The level of significance of the variable for guarantees has improved in comparison with the previous case, and guarantees have positive impacts on Czech exports. Variables GDP, distance, and gross capital fixed formation are highly significant and the importance of political risk also has increased. This parameter is positive. The higher is the level of political risk, the lower is the volume of exports ceteris paribus. The dummy variable denoting Eastern Europe countries is significant and positive. We can expect higher exports to countries which are in the immediate proximity of the Czech Republic. In addition, Czech exports to countries of Eastern Europe are relatively high. On the other hand, dummy variables denoting countries from Africa or Latin America are significant only at the $10 \%$ level. The influence of these countries on the level of exports is not unambiguous.

There is a possibility that the pattern of behavior of our explanatory variables in the dynamic data generating process is not uniform and our data set behaves as data from a variety of countries with heterogeneous behavior (Benáček and Víšek, 2000 and Michalíková and Galeotti, 2010). This heterogeneous behavior of some specific 
individual countries can not be uncovered by using regional dummy variables (for whole continents or parts of continents). This means that it is difficult to estimate our models using an OLS estimator or using a GMM estimator which includes all observations into one model in an attempt at obtaining unambiguous estimates. Our setting may be compared to Benáček and Víšek (1999) who analyzed 91 industries of the Czech economy and realized that this population appeared to consist of two segments. The first segment of their data contained industries in which the majority of firms behaved like in a well-functioning market economy while the other segment contained industries where firms behaved still like under socialist paternalism.

Therefore, in this section we use one of the robust techniques of estimation that solve the problem of heterogeneous patterns in data sets. Out of several robust estimators available, we use the simple Least Trimmed Square estimator (LTS) with a leverage point which was originally developed by Ruppert and Carroll (1980). The advantage of this estimator is a high breakdown point (which is the smallest fraction of outlying observation that can cause a breakdown of the estimator) on the one hand and the possibility of excluding whole polluting countries or couples of polluting years from the data set on the other hand. We can describe the algorithm of this estimator as follows.

We consider the standard linear regression model

$$
Y_{i}=\beta X_{i}+\varepsilon_{i}
$$

where $Y_{i}$ is the response variable for the $i$-th case, $X_{i} \in R^{p}$ is the vector of explanatory variables for the $i$-th case, $\beta$ is the vector of regression coefficients and $\varepsilon_{i}$ is the error term of the $i$-th case. For an arbitrary $b \in R^{p}$, we shall denote by $r_{i}(b)=Y_{i}-b X_{i}$ the $i$-th residual at $b$. Further, we shall use $r_{(i)}^{2}(b)$ for the $i$-th order statistics among the squared residuals. Finally, let us define the LTS estimator by 
the following minimization:

$$
b^{L T S}=\arg \min \sum_{i=1}^{h} r_{(i)}^{2}(b)
$$

where $n / 2 \leq h \leq n$ and the minimization is performed over all $b \in R^{k}$ (Rousseeuw and Leroy, 1987 and Víšek, 1996). In other words, in this minimization we are looking for such an argument $b \in R^{p}$ for which the sum of $h$ smallest squared residuals is minimal. Finally, we build an OLS estimator for these $h$ observations.

These methods were not much used in the past because of their extreme requirements both of memory and of the speed of computers. Even nowadays, each estimation can take minutes (especially for large data sets). Of course there is a question how to select $h$. Rousseeuw and Leroy (1987) showed that putting $h=[(n+1) / 2]+[p / 2]$ (where $[a]$ denotes the integer part of $a)$, we obtain the maximal breakdown point. However, in practice it appears that we do not need the maximal breakdown point and we can select a larger $h$.

Since we are limited by the dynamic form of model (3) (because of the presence of the lagged value of the response variable on the right side of the equation, it is not so easy to exclude some observations from the data set), we decided to exclude a whole country or countries. Therefore, we will use this technique only as a diagnostic tool, and we will determine if the LTS estimator would systematically exclude (almost) a whole country or countries during the period of consideration.

In Table 6 we present the results of experimentations with estimating the static model using LTS. We decided to report the results of the LTS estimation with $h=0.7$. This means that the LTS algorithm excluded $30 \%$ of the observations. On the basis of selected outliers, we decided to drop some countries where more than $60 \%$ of yearly observations within one country had been denoted as outliers. Results suggest that these countries are mostly located in Africa, Central or South America or Asia. Therefore, we first estimate separately three models in which these countries are excluded using fixed effects. In the first model we drop from the 


\begin{tabular}{|ccccccc|}
\hline \hline & $1 \mathrm{a}$ & $1 \mathrm{~b}$ & $1 \mathrm{c}$ & 2 & $3 \mathrm{a}$ & $3 \mathrm{~b}$ \\
\hline $\ln \left(\right.$ guarantee $\left._{i t}\right)$ & $0.011^{* * *}$ & $0.011^{* * *}$ & $0.012^{* * *}$ & $0.012^{* * *}$ & $0.014^{* * *}$ & $0.013^{* * *}$ \\
& $(0.003)$ & $(0.003)$ & $(0.003)$ & $(0.003)$ & $(0.003)$ & $(0.003)$ \\
$\ln \left(G D P_{i t}\right)$ & $0.370^{* * *}$ & $0.175^{* * *}$ & $0.216^{* * *}$ & $0.255^{* * *}$ & $0.203^{* * *}$ & $0.246^{* * *}$ \\
& $(0.086)$ & $(0.057)$ & $(0.059)$ & $(0.079)$ & $(0.058)$ & $(0.060)$ \\
$\ln \left(\right.$ dist $\left._{i}\right)$ & $-4.739^{* * *}$ & $-3.986^{* * *}$ & $-4.100^{* * *}$ & $-3.556^{* * *}$ & $-3.321^{* * *}$ & $-3.873^{* * *}$ \\
& $(1.290)$ & $(1.091)$ & $(1.082)$ & $(1.328)$ & $(1.200)$ & $(1.119)$ \\
$\ln \left(\right.$ pop $\left._{i t}\right)$ & $2.828^{* * *}$ & $2.858^{* * *}$ & $2.847^{* * *}$ & $2.502^{* * *}$ & $2.581^{* * *}$ & $2.746^{* * *}$ \\
& $(0.521)$ & $(0.469)$ & $(0.461)$ & $(0.550)$ & $(0.522)$ & $(0.477)$ \\
$\ln \left(G F C F_{i t}\right)$ & $0.397^{* *}$ & $0.427^{* * *}$ & $0.434^{* * *}$ & $0.435^{* * *}$ & $0.411^{* * *}$ & $0.361^{* * *}$ \\
& $(0.130)$ & $(0.142)$ & $(0.134)$ & $(0.134)$ & $(0.142)$ & $(0.131)$ \\
$\ln \left(M I_{i t}\right)$ & -0.199 & -0.413 & -0.429 & $-0.367^{*}$ & $-0.690^{* * *}$ & $-0.557^{* *}$ \\
& $(0.212)$ & $(0.269)$ & $(0.253)$ & $(0.211)$ & $(0.247)$ & $(0.252)$ \\
$\ln \left(\right.$ ris $\left._{i t}\right)$ & $0.94^{*}$ & $0.259^{* *}$ & $0.196^{*}$ & $0.292^{* *}$ & $0.261^{* *}$ & $0.201^{*}$ \\
& $(0.116)$ & $(0.110)$ & $(0.113)$ & $(0.114)$ & $(0.111)$ & $(0.104)$ \\
\hline Number of obs. & 1224 & 1363 & 1363 & 1092 & 1173 & 1289 \\
Number of groups & 124 & 139 & 137 & 110 & 120 & 131 \\
Excluded obs. & $14 \%$ & $6 \%$ & $6 \%$ & $23 \%$ & $18 \%$ & $9 \%$ \\
Adjusted $R^{2}$ & 0.95 & 0.95 & 0.95 & 0.96 & 0.95 & 0.95 \\
\hline \hline
\end{tabular}

Table 6: LTS estimation - static model. Notes: * significant at 10\%; ** significant at $5 \%$; ${ }^{* * *}$ significant at $1 \%$. Robust (White heteroskedastic consistent) standard errors in brackets. Specific effects dummies are not reported. Hausman test rejects the random effects model. Response variable: logarithm of export. All variables are in logarithm. Zero values replaced by number 1. Excluded states: 1a - African, 1b - Central American, 1c - Asian, 2 - African, Central American, Asian together, $3 \mathrm{a}$ - countries with more than $70 \%$ of outliers, $3 \mathrm{~b}$ - countries with more than $80 \%$ of outliers. 


\begin{tabular}{|ccccccc|}
\hline \hline & $1 \mathrm{a}$ & $1 \mathrm{~b}$ & $1 \mathrm{c}$ & 2 & $3 \mathrm{a}$ & $3 \mathrm{~b}$ \\
\hline $\ln \left(\right.$ Export $\left._{t-1}\right)$ & $0.502^{* * *}$ & $0.523^{* * *}$ & $0.502^{* * *}$ & $0.529^{* * *}$ & $0.534^{* * *}$ & $0.579^{* * *}$ \\
& $(0.109)$ & $(0.087)$ & $(0.075)$ & $(0.141)$ & $(0.093)$ & $(0.086)$ \\
$\ln \left(\right.$ guarantees $\left._{\text {it }}\right)$ & $0.032^{* *}$ & $0.044^{* * *}$ & $0.036^{* *}$ & $0.028^{* *}$ & $0.029^{* *}$ & $0.029^{* *}$ \\
& $(0.014)$ & $(0.017)$ & $(0.016)$ & $(0.012)$ & $(0.014)$ & $(0.013)$ \\
$\ln \left(\right.$ GDP $\left._{i t}\right)$ & $0.407^{* * *}$ & $0.524^{* * *}$ & $0.607^{* *}$ & $0.240^{* *}$ & $0.290^{* *}$ & $0.272^{* *}$ \\
& $(0.112)$ & $(0.163)$ & $(0.142)$ & $(0.105)$ & $(0.136)$ & $(0.116)$ \\
$\ln \left(\right.$ dist $\left._{i}\right)$ & $-0.469^{* * *}$ & $-0.272^{* *}$ & $-0.333^{* * *}$ & $-0.526^{* *}$ & $-0.506^{* * *}$ & $-0.451^{* * *}$ \\
& $(0.162)$ & $(0.131)$ & $(0.118)$ & $(0.237)$ & $(0.184)$ & $(0.162)$ \\
$\ln \left(\right.$ pop $\left._{i t}\right)$ & 0.099 & 0.008 & -0.041 & $0.391^{* *}$ & $0.370^{*}$ & $0.333^{*}$ \\
& $(0.100)$ & $(0.102)$ & $(0.083)$ & $(0.198)$ & $(0.194)$ & $(0.192)$ \\
$\ln \left(G F C F_{i t}\right)$ & $0.557^{* *}$ & $0.839^{* *}$ & $0.768^{* *}$ & $0.710^{* * *}$ & $0.735^{* * *}$ & $0.647^{* * *}$ \\
& $(0.260)$ & $(0.354)$ & $(0.315)$ & $(0.249)$ & $(0.260)$ & $(0.227)$ \\
$\ln \left(M_{i t}\right)$ & -0.514 & $-1.662^{*}$ & $-1.609^{* *}$ & -0.644 & -0.946 & -0.880 \\
$\ln \left(\right.$ ris $\left._{\text {it }}\right)$ & $(0.655)$ & $(0.816)$ & $(0.748)$ & $(0.678)$ & $(0.705)$ & $(0.548)$ \\
& $0.583^{* *}$ & $0.612^{*}$ & 0.401 & $0.519^{* *}$ & $0.461^{*}$ & $0.354^{* *}$ \\
Number of obs. & $(0.300)$ & $(0.316)$ & $(0.286)$ & $(0.246)$ & $(0.249)$ & $(0.240)$ \\
Number of groups & 1122 & 1179 & 1214 & 1041 & 1126 & 1156 \\
Excl. observations & 123 & 130 & 1132 & 111 & 121 & 125 \\
Hansen test $(p$-value $)$ & $9 \%$ & $4 \%$ & $2 \%$ & $15 \%$ & $9 \%$ & $\%$ \\
A-B AR $(1)(p$-value $)$ & 0.081 & 0.146 & 0.126 & 0.169 & 0.164 & 0.111 \\
A-B AR(2) $(p$-value $)$ & 0.052 & 0.000 & 0.000 & 0.000 & 0.000 & 0.000 \\
Pseudo $R^{2}$ & 0.20 & 0.19 & 0.18 & 0.21 & 0.20 & 0.20 \\
LLC test $(p$-value $)$ & 0.000 & 0.000 & 0.000 & 0.000 & 0.000 & 0.000 \\
\hline \hline
\end{tabular}

Table 7: LTS estimation - dynamic model. Notes: * significant at $10 \% ;{ }^{* *}$ significant at $5 \%$; *** significant at $1 \%$. Robust (White heteroskedastic consistent) standard errors in brackets. Specific effects dummies are not reported. Response variable: logarithm of export. All variables are in logarithm. Zero values replaced by number 1. Excluded states: 1a - African, 1b - Central American, 1c - Asian, 2 - African, Central American, Asian together, $3 \mathrm{a}$ - countries with more than $70 \%$ of outliers, $3 \mathrm{~b}$ - countries with more than $80 \%$ of outliers. 
data set some African countries ${ }^{1}$ for which more than $60 \%$ of yearly observations have been denoted as outliers by the LTS algorithm with $h=0.7$. Similarly, in the second model we drop from the data set contaminated Central American countries ${ }^{2}$ and in the third model we drop contaminated Asian countries ${ }^{3}$. These models are summarized in Table 6 in columns 1a, 1b and 1c. We also estimated the model where we dropped contaminated countries together from Africa, Central America and Asia as mentioned above (column 2). Finally we drop countries where more than $70 \%^{4}$ and $80 \%^{5}$ of the years have been deleted, regardless of type of country or continent (columns $3 \mathrm{a}$ and $3 \mathrm{~b})$.

Experiments with estimating the dynamic model by GMM using LTS as a diagnostic tool with $h=0.7$ leads us to the same steps as in the previous case, and we drop similar countries: small or underdeveloped countries of Africa, Asia and Central America (or South America) with low volume of exports. The results are summarized in Table 7. As in the case of the static model, we decided to estimate six different models: in columns $1 \mathrm{a}, 1 \mathrm{~b}$ and $1 \mathrm{c}$ we drop some countries of Africa ${ }^{6}$, Central America ${ }^{7}$ and Asia $^{8}$ (with at least $60 \%$ of the years deleted by LTS), in column 2 we delete countries from all three continents together $(60 \%$ of the years deleted by LTS). Finally we estimate two models (3a and $3 b)$ where we delete countries in which more than $70 \%^{9}$ and $80 \%^{10}$ of the years, respectively, have been marked by

\footnotetext{
${ }^{1}$ Algeria, Burkina Faso, Burundi, Cameroon, Gabon, Guinea, Malawi, Morocco, Mozambique, Namibia, Niger, South Africa, Sudan, Tunisia, Uganda, Zambia, Zimbabwe, Madagascar, the Seychelles

${ }^{2}$ Barbados, Belize, El Salvador, Grenada, Jamaica, Nicaragua

${ }^{3}$ Brunei, Cambodia, Hong Kong, the Maldives, Mongolia, Oman, Qatar, Singapore

${ }^{4}$ Algeria, Burundi, Burkina Faso, Burundi, Cambodia, Cameroon, El Salvador, Gabon, Grenada, Hong Kong, Jamaica, Madagascar, Malawi, the Maldives, Mongolia, Morocco, Mozambique, Namibia, Niger, Oman, Singapore, Uganda, Zambia

${ }^{5}$ Algeria, Burundi, Cambodia, Cameroon, El Salvador, Grenada, Hong Kong, Madagascar, Malawi, Mongolia, Niger, Singapore

${ }^{6}$ Botswana, Burkina Faso, Cameroon, Central African Republic, Gabon, the Gambia, Guinea, Madagascar, Mauritius, Namibia, Niger, the Seychelles, Sudan, Uganda

${ }^{7}$ Antique Barbuda, Belize, Dominican Republic, Grenada, Nicaragua, Panama, Uruguay

${ }^{8}$ Brunei Darussalam, Cambodia, Oman, Qatar, Turkmenistan

${ }^{9}$ Antique Barbuda, Belize, Burkina Faso, Cambodia, Central African Republic, Dominican Republic, Gabon, Grenada, Guinea, Namibia, Niger, Panama, Qatar, the Seychelles, Sudan, Turkmenistan

${ }^{10}$ Antique Barbuda, Belize, Burkina Faso, Cambodia, Dominican Republic, Gabon, Grenada, Guinea, Niger, Qatar, the Seychelles, Turkmenistan
} 
LTS as outliers.

The tests for validity of instruments do not suggest the problem of over-identification. Hansen test rejects the null hypothesis and the Arellano-Bond $\operatorname{AR}(2)$ test does not suggest second-order serial correlation.

Now we will comment on the results of both static and dynamic models. We can see that particularly in the dynamic model the significance of some estimated parameters increased. Our key variable export guarantees is significant in all cases. This conclusion is related to both the static and dynamic model. We can conclude that after deleting polluting observations from the data set, the result changed and the statistical significance of some parameters increased. The percentage share of deleted states is always under $15 \%$. These states represent small (but influential) subpopulation of countries which makes our data heterogeneous and behaves differently. As in the previous case these countries mostly represent regions with low volume of Czech exports or guarantees.

The significance of GDP and distance have not changed, these key variables in the gravity model are still significant. The distance variable is negative and GDP is positive, which is consistent with our assumptions. An interesting increase in statistical significance occurred in the case of political risk. In half of all the estimated models, this variable is significant. Moreover, the reached level of significance is at least $10 \%$ with the exception of one case. The estimated coefficients are positive. This means that countries with lower political risk receive more exports. With respect to the improvement in significance levels, we can conclude that the heterogeneity pattern of countries has been evidenced and the use of robust regression and elimination of polluting observations is well founded. Moreover, the problem of outlying observations in panel data models is still frequently disregarded. Although the usefulness of robust estimators in linear regression is well established, the development of robust procedures for panel data is still the object of continuing research (Bramati and Croux, 2004). 


\section{Conclusions}

In this paper we analyzed whether public export credit guarantees lead to a significant amount of additional exports. Export promotion through export guarantees should mitigate specific frictions in international trade. This stimulates an effort to enhance exports by providing guarantees against export risks. With respect to relevant literature and theoretical models, we expect a positive effect of guarantees. For example, regions with a higher degree of insecurity should benefit more from insurance coverage. We focused on the case of the Czech Republic as a representative of a small open post-transitional economy with a small home market base. While Czech exports flow mainly to developed European countries, export credit guarantees push exports mainly to developing European countries.

We estimated the gravity model where exports are expressed as a function of country size and trades costs. In addition to basic explanatory variables of the gravity model, we also included export guarantees as a measure for the reduction of border barrier trade costs, and we also included several additional controlling variables. In comparison with previous empirical approaches, we make several important extensions. We worked with unbalanced panel data including 160 countries between 1996-2008.

Firstly we estimated two gravity models of exports in the Czech Republic, the static model by LSDV estimator and the dynamic model by System GMM. We found that guarantees are a significant factor that influences positively the volume of exports in the Czech Republic. We found that our conclusions were ambiguous: while in the static model guarantees are a highly significant factor, from the results of the dynamic model we could not answer explicitly whether export promotion is successful. Since the estimated coefficients can be expressed as an elasticity, we estimated a short-run elasticity of 0.011 . This suggests that a one per cent increase in the newly covered businesses creates additional short-run exports in the range of 1 per cent. In comparison with the long-run results (where estimated elasticity reached $6.4 \%$ ), this effect is small. The explanation for this difference between 
effects of public export guarantees on export flows is the lag between the time when a promotion is provided and the actual shipment of the good.

There exist additional factors that affect the volume of exports in our model. We found that market forces, described by GDP, distance, political risk or gross fix capital formation are significant in our econometric model. Specifically, higher GDP, short distance or lower political risk have a positive impact on Czech exports. Bigger market size offers more opportunities for exporters.

Since we expected that guarantees are a significant factor, and since the statistical significance of guarantees in the dynamic model was not really convincing, using additional tests we decided to check whether guarantees in both the short-run and long-run really are (or are not, respectively) significant. Additional testing with new dummy variables (for Africa, Eastern Europe and Latin America) suggest that countries of Eastern Europe have a positive impact on Czech exports. Nevertheless, we did not manage to show the influence of other regions on exports. Robust regression is an econometric tool suitable for this purpose. Robust estimators can solve situations where data are polluted by some outlying observations and these observations can totally distort the significance of parameters. Our effort was to confirm or refute the conclusions obtained by LSDV and System GMM. We decided to estimate the gravity equation with the use of a robust statistics technique.

Therefore in the second part of our econometrical investigation we used the Least Trimmed Squares estimator. This estimator is based on the minimization of squared residuals, but the largest residuals are not included in the minimization. This allows the fit to stay away from the outliers. We found estimates of several alternative models where we dropped certain countries from the data set. These deleted countries denoted as outliers can be mostly characterized by low volume of received exports and low volume of Czech export promotion. Geographically, they can be classified into three groups - states of Africa, states of Asia and states of Central America. A common feature of these countries is lower GDP, higher distance from the Czech Republic, and lower volume of exports. Higher political 
risk is another reason why the volume of exports from the Czech Republic to these countries is so low. As a consequence of these factors, guarantees to these countries are low as well. The behavior of these countries in the set of all countries is different and they are denoted as outliers. After the removal of these countries the results were in general more statistically significant, especially in the case of the dynamic model: variable guarantees are significant at the $1 \%$ or $5 \%$ level. Therefore this set of additional regressions applied to the dynamic model supports the conclusion that estimates obtained by System GMM in the first part of the paper were influenced by outliers. We conclude that we are not able to reject the hypothesis that export promotion is successful in both the short- and long-run. Export guarantees can reduce the uncertainty of exports. This risk reduction increases exports to (risky) markets where exporting companies would not sell otherwise. Moreover, guarantees which enable an initial export to some country can make future exports to this country more likely. Public export agencies may also bring positive effects by gathering information about foreign markets. Therefore, they can reduce entry costs.

Moreover, larger economies can be characterized as recipients of higher exports and the volume of exports declines with growing distance. The political risk variable is statistically significant in three dynamic models. Since the political risk represents an important friction to international trade, the positive sign of estimated parameters supports our hypothesis that countries with higher political risk receive less exports. Countries with less stable governments or a higher level of corruption are less likely to attract Czech exports.

At this point we would like to stress the fact that although robust methods are well developed nowadays, there is still a shortage of literature and practical implementation of robust methods on panel data. Some new possibilities for improving our analysis include, for example, use of the bootstrap method for LTS (Skuhrovec, 2010), robustification of GMM or robust methods for fixed effects (Bramati and Croux, 2004). Another obvious extension would be to investigate the effect of additional explanatory variables for our model: infrastructure, trade policy variables 
or border effects.

\section{References}

[1] James E. Anderson. A theoretical foundation for the gravity equation. American Economic Review, 69(1):106-16, March 1979.

[2] James E. Anderson and Eric van Wincoop. Gravity with gravitas: A solution to the border puzzle. American Economic Review, 93(1):170-192, March 2003.

[3] Manuel Arellano and Stephen Roy Bond. Some tests of specification for panel data: Monte Carlo evidence and an application to employment equations. Review of Economic Studies, 58(2):177-297, April 1991.

[4] Manuel Arellano and Olympia Bover. Another look at the instrumental variable estimation of error-components models. Journal of Econometrics, 68(1):29-51, July 1995.

[5] Badi H. Baltagi. Econometric Analysis of Panel Data. Wiley, 1998.

[6] Ernst Baltensperger and Nils Herger. Exporting against risk? Theory and evidence from public export insurance schemes in OECD countries. Open Economies Review, 20(4):545-563, September 2009.

[7] Vladimír Benáček and Jan Ámos Víšek. The determinants of FDI flows into Czech manufacturing industries: Theoretical background for an empirical study. WIFO Seminar, Vienna, 1999.

[8] Vladimír Benáček and Jan Ámos Víšek. Přímé zahraniční investice v české ekonomice: praxe, teorie a aplikace. Politicka Ekonomie, 1:7-24, 2000.

[9] Jeffrey Bergstrand. The gravity equation in international trade: Some microeconomics foundations and empirical evidence. The Review of Economics and Statistics, 67(3):474-481, August 1985.

[10] Richard Blundell and Stephen Roy Bond. Initial conditions and moment restrictions in dynamic panel data models. Review of Economic Studies, 87(1):115143, August 1998.

[11] Steve Bond. Dynamic panel data models: A guide to micro data methods and practice. Cemmap working paper 09/02, 2002.

[12] Maria C. Bramati and Christophe Croux. Robust estimators for the fixed effects panel data model. Econometrics Journal, 10:1-19, 2004.

[13] Martin Burger, Frank van Oort, and Gert-Jan Linders. On the specification of the gravity model of trade: Zeros, excess zeros and zero-inflated estimation. ERIM Report Series, 4(2):167-190, 2009.

[14] Peter Egger and Michael Pfaffermayer. Estimating long and short run effects in static panel models. Econometric Review, 23(3):199-214, January 2005. 
[15] Peter Egger and Thomas Url. Public export credit guarantees and foreign trade structure: Evidence from Austria. The World Economy, 29(4):399-418, April 2006.

[16] Christian Gourieroux, Alain Monfort, and Alain Trognon. Pseudo maximum likelihood methods: Applications to Poisson models. Econometrica, 52(3):701$720,1984$.

[17] Lars Peter Hansen. Large sample properties of generalized methods of moments estimator. Econometrica, 50(4):1029-54, July 1982.

[18] Jerry A. Hausman. Specification tests in econometrics. Econometrica, 46(6):1251-71, Nomvember 1978.

[19] Elhanan Helpman, Marc Melitz, and Yona Rubinstein. Estimating trade flows: Trading partners and trading volumes. The Quarterly Journal of Economics, 123(2):441-487, 2008.

[20] Rob Jongman. Data analysis in community and landscape ecology. Cambridge University Press, 2002.

[21] Ruth A. Judson and Ann L. Owen. Estimating dynamic panel data models: A practical guide for macroeconomists. Board of Governors of the Federal Reserve System, Finance and Economics Discussion Series, 3, 1996.

[22] Andrew Levin, Lin Chien-Fu, and James Chia-Shang Chu. Panel unit root tests: Asymptotic and finite sample properties. Journal of Econometrics, 108(1):1-24, 2002.

[23] Eva Michalíková and Elisa Galeotti. Determinants of FDI in Czech manufacturing industries between 2000-2007. South East European Journal of Economics and Business, 5(2):21-32, November 2010.

[24] Jan Ámos Víšek. On high breakdown point estimation. Computational Statistics, 11:137-146, 1996.

[25] Christoph Moser, Thorsten Nestmann, and Michael Wedow. Political risk and export promotion: evidence from Germany. The World Economy, 31(6):781803, June 2008.

[26] Stephen J. Nickell. Biases in dynamic models with fixed effects. Econometrica, 49(6):1417-26, November 1981.

[27] Robert M. O'Brien. A caution regarding rules of thumb for variance inflation factors. Quantity and Quality, 41:673-690, 2007.

[28] Anca Porojan. Trade flows and spatial effects: The gravity model revisited. Open Economies Review, 12(3):265-280, July 2001.

[29] Pentti Pöyhönen. A tentative model for the volume of trade between countries. Weltwirtschaftliches Archiv, 90(1):93-100, 1963. 
[30] David Roodman. How to do xtabond2: An introduction to Difference and System GMM in Stata. Stata Journal, 9(1):86-136, March 2009.

[31] Peter Rousseeuw and Anick Leroy. Robust Regression and Outlier Detection. Wiley, 1987.

[32] David Ruppert and Raymond Carroll. Trimmed least squares estimation in linear models. Journal of American Statistical Association, 48:463-466, 1980.

[33] J.M.C. Santos Silva and Silvana Tenreyro. The log of gravity. The Review of Economics and Statistics, 88(4):641-658, 2006.

[34] Jiří Skuhrovec. Analysis of LWS Empirical Properties Using Bootstrap Methods. Diploma thesis, Czech Technical University in Prague, 2010.

[35] Jan Tinbergen. Shaping the World Economy: Suggestions for an International Economic Policy. New York: The Twentieth Century Fund, 1962. 


\section{Appendix}

\section{Developed countries:}

Australia, Austria, Belgium, Canada, Denmark, Finland, France, Germany, Greece, Hong Kong SAR, Iceland, Ireland, Israel, Italy, Japan, Korea, Luxembourg, Netherlands, New Zealand, Norway, Portugal, Singapore, Spain, Sweden, Switzerland, Taiwan, United Kingdom, United States.

\section{Developing European countries:}

Albania, Bosnia and Herzegovina, Bulgaria, Croatia, Cyprus, Estonia, Hungary, Latvia, Lithuania, Macedonia, Malta, Montenegro, Poland, Romania, Serbia, Slovak Republic, Slovenia.

Commonwealth of Independent State:

Armenia, Azerbaijan, Belarus, Georgia, Kazakhstan, Kyrgyzstan, Moldova, Russia, Tajikistan, Turkmenistan, Ukraine, Uzbekistan.

\section{America:}

Antigua and Barbuda, Argentina, Bahamas, Barbados, Belize, Bolivia, Brazil, Chile, Colombia, Costa Rica, Dominica, Dominican Republic, Ecuador, El Salvador, Grenada, Guatemala, Guyana, Haiti, Honduras, Jamaica, Mexico, Nicaragua, Panama, Paraguay, Peru, Suriname, Trinidad and Tobago, Uruguay, Venezuela.

\section{Asia:}

Afghanistan, Bahrain, Bangladesh, Brunei Darussalam, Cambodia, China, India, Indonesia, Iran, Jordan, Kuwait, Laos, Lebanon, Malaysia, the Maldives, Mongolia, Myanmar, Nepal, Oman, Pakistan, Philippines, Qatar, Saudi Arabia, Syrian Arab Republic, Thailand, Turkey, United Arab Emirates, Vietnam, Yemen.

\section{Africa:}

Algeria, Angola, Benin, Botswana, Burkina Faso, Burundi, Central African Republic, Cameroon, Chad, Congo, Côte d'Ivoire, Djibouti, Egypt, Eritrea, Ethiopia, Gabon, the Gambia, Ghana, Kenya, Liberia, Libya, Madagascar, Malawi, Mali, Mauritania, Mauritius, Morocco, Mozambique, Namibia, Niger, Nigeria, Rwanda, Senegal, the Seychelles, Sierra Leone, South Africa, Sudan, Tanzania, Togo, Tunisia, Uganda, Zambia, Zimbabwe.

Table 8: Classification of states. 


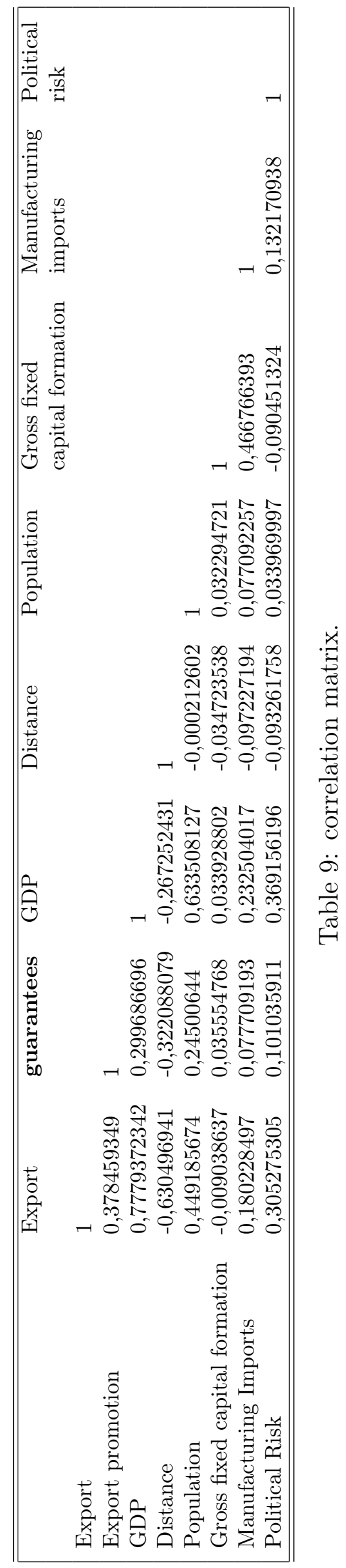




\begin{tabular}{|c|c|c|c|c|c|}
\hline & $\begin{array}{l}\text { FE } \\
\text { (I) }\end{array}$ & $\begin{array}{c}\text { System } \\
\text { GMM } \\
\text { (II) }\end{array}$ & $\begin{array}{l}\mathrm{FE} \\
\text { (III) }\end{array}$ & $\begin{array}{c}\text { System } \\
\text { GMM } \\
\text { (IV) }\end{array}$ & $\begin{array}{c}\text { PPML } \\
(\mathrm{V}) \\
(\mathrm{V})\end{array}$ \\
\hline $\ln \left(\right.$ Export $\left._{t-1}\right)$ & - & $\begin{array}{c}0.503^{* * *} \\
(0.079)\end{array}$ & - & $\begin{array}{c}0.503^{* * *} \\
(0.079)\end{array}$ & - \\
\hline $\ln \left(\right.$ guarantees $\left._{i t}\right)$ & $\begin{array}{c}0.010^{* * *} * \\
(0.002)\end{array}$ & $\begin{array}{l}0.027^{*} \\
(0.014)\end{array}$ & $\begin{array}{c}0.011^{* * *} \\
(0.002)\end{array}$ & $\begin{array}{l}0.031^{*} \\
(0.016)\end{array}$ & $\begin{array}{c}0.029^{* * *} \\
(0.011)\end{array}$ \\
\hline $\ln \left(G D P_{i t}\right)$ & $\begin{array}{c}0.230 * * * \\
(0.060)\end{array}$ & $\begin{array}{c}0.270 * * \\
(0.132)\end{array}$ & $\begin{array}{c}0.230^{* * *} \\
(0.060)\end{array}$ & $\begin{array}{c}0.270^{* *} \\
(0.132)\end{array}$ & $\begin{array}{c}0.166^{* * *} \\
(0.000)\end{array}$ \\
\hline $\ln \left(\right.$ dist $\left._{i}\right)$ & $\begin{array}{c}-4.406^{* * *} \\
(1.075)\end{array}$ & $\begin{array}{c}-0.696 * * * \\
(0.135)\end{array}$ & $\begin{array}{c}-4.407^{* * *} \\
(1.075)\end{array}$ & $\begin{array}{c}-0.695^{* * *} \\
(0.135)\end{array}$ & $\begin{array}{c}-3.290 * * * \\
(0.125)\end{array}$ \\
\hline $\ln \left(\right.$ pop $\left._{i t}\right)$ & $\begin{array}{c}2.957^{* * *} \\
(0.457)\end{array}$ & $\begin{array}{c}0.216 \\
(0.169)\end{array}$ & $\begin{array}{c}2.956^{* * *} \\
(0.457)\end{array}$ & $\begin{array}{c}0.214 \\
(0.169)\end{array}$ & $\begin{array}{c}1.199 * * * \\
(0.123)\end{array}$ \\
\hline $\ln \left(G F C F_{i t}\right)$ & $\begin{array}{c}0.427^{* * *} \\
(0.139)\end{array}$ & $\begin{array}{l}1.096^{* *} \\
(0.439)\end{array}$ & $\begin{array}{c}0.426^{* * *} \\
(0.139)\end{array}$ & $\begin{array}{l}1.096^{* *} \\
(0.439)\end{array}$ & $\begin{array}{c}0.075^{* * *} \\
(0.234)\end{array}$ \\
\hline $\ln \left(M I_{i t}\right)$ & $\begin{array}{l}-0.367 \\
(0.254)\end{array}$ & $\begin{array}{c}0.210 \\
(0.508)\end{array}$ & $\begin{array}{l}-0.368 \\
(0.254)\end{array}$ & $\begin{array}{c}0.203 \\
(0.510)\end{array}$ & $\begin{array}{l}-0.188 \\
(0.651)\end{array}$ \\
\hline $\ln \left(r i s k_{i t}\right)$ & $\begin{array}{l}0.187^{*} \\
(0.112)\end{array}$ & $\begin{array}{c}0.175 \\
(0.229)\end{array}$ & $\begin{array}{l}0.187^{*} \\
(0.112)\end{array}$ & $\begin{array}{c}0.176 \\
(0.229)\end{array}$ & $\begin{array}{c}0.222^{*} \\
0.101\end{array}$ \\
\hline Number of obs. & 1429 & 1237 & 1429 & 1237 & 1429 \\
\hline Number of groups & 145 & 137 & 145 & 137 & 145 \\
\hline adj./pseudo $R^{2}$ & 0.95 & 0.19 & 0.95 & 0.19 & 0.93 \\
\hline Hansen test ( $p$-value) & - & 0.063 & & 0.065 & - \\
\hline $\mathrm{A}-\mathrm{B} \operatorname{AR}(1)(p$-value $)$ & - & 0.000 & & 0.000 & - \\
\hline $\mathrm{A}-\mathrm{B} \operatorname{AR}(2)(p$-value $)$ & - & 0.639 & & 0.640 & - \\
\hline LLC test ( $p$-value) & - & 0.000 & - & 0.000 & - \\
\hline
\end{tabular}

Table 10: Sensitivity analyses - zero observations. Static and dynamic models. Notes: Zero values replaced by 0.1 in models (I) and (II), zero values replaced by 0.5 in models (III) and (IV), Poisson pseudo-maximum likelihood (PPML) estimator $(\mathrm{V}) .{ }^{*}$ significant at $10 \%$; ** significant at $5 \%$; *** significant at $1 \%$. Robust (White heteroskedastic consistent) standard errors in brackets. Specific effects country dummies are not reported. Hausman test rejects the random effects model. Response variable: logarithm of export. All variables are in logarithm. 


\section{Working Paper Series}

ISSN 1211-3298

Registration No. (Ministry of Culture): E 19443

Specific research support and/or other grants the researchers/publications benefited from are acknowledged at the beginning of the Paper.

(c) Karel Janda, Eva Michalíková, and Jiří Skuhrovec, 2012

All rights reserved. No part of this publication may be reproduced, stored in a retrieval system or transmitted in any form or by any means, electronic, mechanical or photocopying, recording, or otherwise without the prior permission of the publisher.

Published by

Charles University in Prague, Center for Economic Research and Graduate Education (CERGE) and

Economics Institute ASCR, v. v. i. (EI)

CERGE-EI, Politických vězňů 7, 11121 Prague 1, tel.: +420 224005 153, Czech Republic.

Printed by CERGE-EI, Prague

Subscription: CERGE-EI homepage: http://www.cerge-ei.cz

Phone: + 420224005153

Email: office@cerge-ei.cz

Web: http://www.cerge-ei.cz

Editor: Michal Kejak

Editorial board: Jan Kmenta, Randall Filer, Petr Zemčík

The paper is available online at http://www.cerge-ei.cz/publications/working_papers/.

ISBN 978-80-7343-264-5 (Univerzita Karlova. Centrum pro ekonomický výzkum a doktorské studium)

ISBN 978-80-7344-256-9 (Národohospodářský ústav AV ČR, v. v. i.) 
CERGE-EI

P.O.BOX 882

Politických vězňů 7

11121 Praha 1

Czech Republic http://www.cerge-ei.cz 